\title{
International Aid, Frontier Securitization, and Social Engineering: Soviet-Xinjiang Development Cooperation during the Governorate of Sheng Shicai $(1933-1944)$
}

\author{
Bruno De Cordier \\ Ghent University, Belgium \\ Bruno.DeCordier@ugent.be
}

\begin{abstract}
This article looks into the nature and dynamics of Soviet assistance to the Governorate of Sheng Shicai, a military de facto state that existed in Xinjiang between 1933 and 1944. Besides discussing how the various forms of Soviet aid shaped the policies of the Governorate, it also examines how Sheng Shicai used the aid to pursue his desire for inclusive patriotism and social modernization into practice. The article further shows how the USSR actively supported Sheng Shicai's development policies in an urge to securitize its borderlands by abetting ideologically aligned state-building and social transformation there. Although it was done with entirely different actors, methods, and within very different political frameworks, the aid securitization and borderland control logic makes this episode a historical forerunner of the state-building and social development aid in international neo-protectorates today.
\end{abstract}

\section{Keywords}

history of international aid - quasi states - Stalinist USS R - Xinjiang - frontier securitization - Sheng Shicai

* The author is a professor at the Department of Conflict and Development Studies of Ghent University in Belgium. He cordially thanks Thierry Kellner of the Département de Sciences Politique at the Université Libre de Bruxelles for his kind help with the verification of the Romanized Chinese terms and names in this article. 
"Sag mir, wer dein Feind ist, und ich sage dir, wer du bist."

[Tell me who your enemy is, and I will tell you who you are.] CARL SCHMITT (1888-1985)

This article examines the wide-ranging assistance that Moscow provided to Sheng Shicai's governorate, a military de facto state that existed in Xinjiang province between 1933 and 1944. It draws on an excellent book by Emma Mawdsley on the so-called emerging donors of international aid. ${ }^{1}$ When reading the section on Soviet aid policies in the chapter on histories and lineages of non-OECD aid, we felt that the USSR's aid policies during the Stalinist era (1922-1953) were treated too briefly. ${ }^{2}$ Contrary to what is explicitly claimed in the book, the USSR under Stalin did engage in a variation of multisector foreign aid, despite its clear drive for rapid internal development and self-sufficiency. At that time, the "Third World" did not exist; indeed, the concept did not appear until 1952. ${ }^{3}$ Most countries and societies in Africa, India, and the Arab and Indonesian spheres were either colonies, protectorates, or mandate territories of one of the major Western European powers (or of Japan, in the case of Korea and northeastern China), or mandate territories of the League of Nations, which were de facto administered by one of these powers.

\section{State Failures and Great Spaces}

Nor did the Moscow leadership perceive these areas and societies as merely a passive extension of the capitalist and imperialist sphere. Although its leaders had largely given up on worldwide revolution export by 1924 in favor of Stalin's "Socialism in One Country" doctrine and no longer explicitly called for all-out

1 Emma Mawdsley, From Recipients to Donors: Emerging Powers and the Changing Development Landscape (London: Zed Books, 2012).

2 Ibid., 49.

3 For an overview and discussion of the evolution of the aid economy, its doctrines and its approaches, see Erik Thorbecke, "The Evolution of the Development Doctrine and the Role of Foreign Aid, 1950-2000," in Finn Tarp and Peter Hjertholm (eds), Foreign Aid and Development: Lessons Learnt and Directions for the Future (London: Routledge, 200o), 17-47. 
decolonization, the USSR, especially during the latter Stalinist years, did have contacts and did offer various forms of support to national movements and native power elites in these areas, including those not of communist or socialist orientation. ${ }^{4}$ Development either cooperation, in its current meaning and practices, did not exist at that time. However, the USSR, besides giving military aid and concluding preferential trade agreements with lower-income countries, did organize civilian aid activities that, in modern development jargon, could be categorized as technical assistance, social development, debt relief, capacity building, and governance reform. While it was not called "development cooperation," the USSR delivered sizeable amounts of aid of this kind to Mongolia from 1929-1936 onward, as well as to communist China after 1949-1952.

It is not well known that the USSR gave aid to unrecognized states in central Eurasia bordering the UssR, like the Governorate of Sheng Shicai (1933-1944) and the East Turkestan Republic of Kulja (1944-1949), which both emerged in Xinjiang. This aid was clearly embedded in a frontier securitization approach that was not only limited to various forms of military presence, but also encompassed active support to state-building and social transformation projects perceived to be ideologically affiliated. Yet what, exactly, was this state-like "Governorate of Sheng Shicai"? Its formation has to be situated against the background of the political fragmentation of the Chinese great space that characterized a large portion of the period between the demise of the Chinese empire in 1911 and the communist takeover in $1949 .{ }^{5}$

With parts of China under control of the communist guerrillas, de facto independent fiefdoms or Japanese occupation, the republican Guomindangled government in Nanjing could often only exert varying degrees of influence through power-sharing agreements with its governors and military commanders, local warlords, native elders, and ethnic minority movements. Today, this situation would be called state failure.

4 For a more in-depth examination, see Odd Arne Westad, The Global Cold War: Third World Interventions and the Making of Our Times (Cambridge: Cambridge University Press, 2005), 53-66. China, or rather, the Chinese great space (which was politically heavily fractured and partly occupied by Japan after 1931-1932), Korea (still a Japanese colony), Iran, and Abyssinia (Ethiopia), both of which were not European colonies despite temporary occupations, played a central role in Moscow's "Third World" strategy back then.

5 We use the term "great space" in the sense of Carl Schmitt's concept of "Großraum" is his book Völkerrechtliche Großraumordnung mit Interventionsverbot für Raumfremde Mächte, which is a geographical area dominated by a power representing a distinct political idea. 
There were several population groups who were instrumental in the spread of Soviet influence in Xinjiang. None of them resembled a proletariat that could be a presumed vector of socialism. The first, paradoxically, consisted of people who had fled the Soviet realm between 1919 and 1931. These included the 13,000 to 18,0oo White and émigré Russians who had settled in and around Kulja (Yining) and Ürümçi, the estimated 190,00o ethnic Kazakhs who had fled the USSR for Xinjiang after then start of the Stalinist collectivization campaigns and the subsequent famine. Although in principle, all of these should have been regarded as breeding grounds for anti-Soviet activities in the region, the Soviet consulate-general in Ürümçi and the consulate in Kulja, made overtures to these groups in order to create a base in the province.

Second, certain Uyghur elite factions - including Khoja notables, members of Xinjiang's religious and tribal aristocracies - as well as Islamic reformers, especially in the Kulja region and in northern Xinjiang, had put their hopes in the USSR to counterweight the dominance of China and to support their aspirations for autonomy or independence. With Xinjiang in a state of anarchy and fragmentation, the pacification and perceived economic and social progress in the USSR also made it an attractive - if idealized - model for some.

Third, and most important, there were Chinese civil servants and military commanders in Xinjiang who were formally subordinated to the republican government in Nanjing, but were in practice largely disconnected from it and looking elsewhere for assistance to consolidate their position and interests. ${ }^{6}$

\section{The Functionality of "Cockpit States"}

The Governorate of Sheng Shicai began in spring 1933 and lasted until his departure in summer 1944. Although Sheng Shicai, who held the military rank of general, was officially governor of Xinjiang province within its official boundaries, the area under his actual control was initially limited to an arc stretching from the Ili Valley to the Ürümçi area and parts of the Jungar plateau in the north of the province, somewhat parallel to the border with the USSR. In

6 Marie-Claire Bergère, "L'influence du modèle soviétique sur la politique des minorités nationales en Chine. La cas du Sinkiang (1949-1962)," Revue française de Science politique, 29, no. 3 (1979): 408; David Wang, "Soviet Citizenship in Xinjiang," Asian Studies Review, 19, no. 3 (1996): 88. See also Raïsa Mirovitskaya, "Kitaiskaya provintsiya Sin'tszyan v Sovetsko-Kitaiskikh otnosheniyakh (1930-1940)," Kitai v mirovoi i regional'noi politike - i sovremennost', 15, no. 15 (2010): 237-247. 
1937, with Soviet backing, his army managed to recapture Kashgar from the $3^{\text {th }}$ Division of Hui commander Ma Zhongying.

They had societies in Sheng Shicai's jurisdiction was overwhelmingly rural and agricultural and had societies dominated by local and micro-regional social identities and regulated by customary law, genealogically defined solidarity groups, and confessional systems, primarily Sunni Islam and micro-regional folk practices. $^{7}$

Due to political instability and the fact that the first modern-method census in Xinjiang was only organized in 1953, there is only a patchy picture of Xinjiang's demography at this time. Yet, a police survey of 1940-1941 put the population of Xinjiang at some 3.73 million of which roughly three-quarters lived in the south and 3.43 million (92.5\%) were Muslim by confession. Ethnically, about $80 \%$ of Xinjiang's population then consisted of Uyghurs or sedentary Turkic microregional groups officially named that way after $1935 ; 8.7 \%$ were Kazakhs living in the Ili Valley and the piedmont of the Altai range, and $1.7 \%$ were Kyrgyz who primarily lived in Ulugqat prefecture and other regions around Kashgar. The Hui (a Sino-Muslim population group), who lived in northern Xinjiang, the Ili Valley and in the cities of the south, reportedly numbered 92,000 or $2.5 \%$ at that time. Finally, the number of Han was estimated at some 187,000 or $5 \%$, with specific concentrations in and around Ürümçi (then also called Dihua in Chinese), Kumul (Hami), and northern Xinjiang in general, hence a member of and, to a lesser extent, in settlements and garrison quarters (hence a member of the so-called Twin Cities) near the major centers in the south. ${ }^{8}$

Ethnically Han, China's dominant majority culture, Sheng Shicai originated from the northeastern Liaoning province, in a part of the country that had long been under active Japanese and Russian influence before it became a semicolony of Japan in 1931. He was thus not a native of Xinjiang nor did he grow up there as a member of the long-established Han minority in the province. Instead, he was initially assigned to the area by the Nanjing government in 1930 as the chief military instructor of Governor Jin Shuren, who already maintained close, if much more pragmatic, ties with the UssR. In that capacity, Sheng Shicai quelled the initially successful Uyghur rebellion in Kumul with

7 For a detailed examination of the social organization of the Uyghur or different Uyghur groups, see Ildikó Bellér-Hann, Community Matters in Xinjiang - Toward a Historical Anthropology of the Uyghur, 1880-1949 (Leiden: Brill, 2008), and, for the Kazakhs, Ian Morrison, "Some Notes on the Kazakhs of Sinkiang," Journal of the Royal Central Asian Society, 36 (1948-49): 67-71.

8 Chang Chih-Yi, "Land Utilization and Settlement Possibilities in Sinkiang," Geographical Review, 39, no. 1 (1949: 62). 
the help of a White émigré Russian unit and some Soviet aircraft, and he was subsequently promoted chief military commander of Xinjiang. Having no broad ethnic or social base in the province, once he became governor through a coup d'état himself, he had to create one through interpersonal networks, mobilizing support among the native population, and an externally backed ideological project.

Although at a certain moment, it had the character of a proper state, Sheng Shicai's governorate was not recognized by other countries - not even the USSR - or by supranational organs like the League of Nations. In that respect, it had many characteristics of so-called quasi states. Also named "de facto states," these are political entities that do have the four basic characteristics and attributes of a state - a territory with formal borders, a permanent population, governance structures, and state symbols - but which are not recognized as independent states by other countries and by supranational institutions. So, while they exist in practice, under international law they do not.

According to Michael Rywkin, quasi states, which have existed throughout modern history, share four characteristics. First, they came into being through secession from a state during a violent ethnic or social conflict or because of the disintegration of a parent state. Second, they have an external patron state that is either taking advantage of their secession or that provides sizeable amounts of assistance to the secessionist entity. Third, quasi states are not recognized by authoritative supranational organs or by any other state, except perhaps the patron state. And fourth, despite the vital need for external support and inputs and the lack of recognition, many quasi sates are able to function as mini-states. Their economy and financial system are usually closely intertwined with those of the patron state, they manage to maintain armed forces and a defense system, and conduct international relations, albeit through officious and informal channels. ${ }^{9}$

In practice, since they are the product of conflict, the contours of a quasi state's actual territory are also in a flux; their officially declared borders often reflect an aspired rather than an actually controlled territory. Also, the purpose of quasi states is not necessarily to achieve internationally recognized independence. ${ }^{10}$ Rather, their purpose and function can also be as a temporary safe haven for a sociocultural community perceived to be under threat, a power

Michael Rywkin, "Le phénomène des 'quasi états', Diogène - Revue internationale des sciences humaines, 2 no. 10 (2005): $3^{2-33}$. Examples of quasi states in the realm of the old USSR are Transnistria, South Ossetia, and, though much more in a flux at the time of writing, Donbass in southeastern Ukraine. Quasi states? The Case of Transnistria," in Natalia Cwicinskaja and Piotr Oleksy (eds), 
base and political lever for counter-elites or renegade segments of elites within a state or great space, or a temporary entity that has to facilitate the (re-)integration in another state or great space. Finally, quasi states can act as a social laboratory, where a societal and ideological model is tested in anticipation of its planned or hoped-for generalization in a larger area that is still to be acquired or reconquered. The latter is of particular relevance for this case study, since de facto states, because they are often still "under construction," often form a framework for the implementation of extraneously championed forms of governance and societal organization that are to anchor influence and secure the borderlands of powers in a given social-geographic area. As such, they function as a 'cockpit' for a political-ideological project.

\section{Externalities As Aid Catalysts}

In this respect, James Fearon and David Laitin, when examining what they call "neo-trusteeship," bring in a number of relevant elements and notions. ${ }^{11}$ Of course, they based themselves on cases and situations that came into being six to seven decades later, after the demise of the USSR itself. Nonetheless, elements characterizing present-day international interventionism in contexts as varied as Bosnia, Kosovo, East Timor, and "rump Somalia" were already present in the cases examined here. Essentially, neo-trusteeship is how to exercise multispectrum control on a given area. "Similar to classical imperialism," Fearon and Laitin elaborate,

these efforts involve a remarkable degree of control over domestic political authority and basic economic functions by foreign countries. In contrast to classical imperialism, in these new forms of rule, subjects are governed by a complex hodgepodge of foreign powers, international and nongovernmental organizations, and domestic institutions rather than by a single imperial trust power asserting monopoly rights within its domain. ${ }^{12}$

$[\ldots]$

In contrast to classical imperialism but in line with the concept of trusteeship, the parties to these complex interventions typically seek an international mandate for their rule. Finally, whereas classical imperialists

Moldova: In Search of Its Own Place in Europe (Bydgoszcz : Oficyna Wydawnicza Epigram, 2013), 55-65.

11 James Fearon and David Laitin, "Neo-Trusteeship and the Problem of Weak States," International Security, 28 , no. 4 (2004): 5-43.

12 Ibid.: 7 . 
conceived of their empires as indefinite in time, the agents of neotrusteeship want to exit as quickly as possible, after intervening to reconstruct or reconfigure states so as to reduce threats arising from either state collapse or rogue regimes threats which are called "bad externalities" that result from the combination of the scientific revolution and political disorder, economic collapse and anger in peripheral societies. ${ }^{13}$

Moscow faced several "bad externalities" in Xinjiang. First, the disintegration of the Chinese great space despite the nominal presence of a central government fed genuine concerns that semi-anarchy could spill over into the southern USSR's border regions. Second, there were economic and geographic concerns, given how close the UssR-Xinjiang border was to the Turksib Railway, the Karaganda mining basin, and the fledgling industrial centers of northern Kazakhstan. ${ }^{14}$

Third, there were concerns that imperial Japan, after it set up a first protectorate in China's northeast in 1931-1932 and further invaded the country in 1937, would capitalize on both the power vacuum and ethno-nationalist aspirations among the native Turkic population of Xinjiang. ${ }^{15}$ Fourth, following the experience with the short-lived first East Turkestan republic (late 1933-spring 1934) in southern Xinjiang, ${ }^{16}$ there was the concern that the establishment of successful political experiments, particularly of an Islamic or Pan-Turkic

13 Ibid., 13 .

14 For an in-depth examination of Stalinist-Soviet interventionism in Xinjiang and the security considerations that drove them, see Vyacheslav Shitko, "Voiska OGPU-NKVD v lokal'nykh voinakh i konfliktakh: 1922-Iyun' 1944 gg," unpublished dissertation no. 61-077/962, Moscow, Defense University, 2007.

15 For a more in-depth examination, see Patrick von zur Mühlen, "Japan und die sowjetische Nationalitätenfrage am Vorabend und während des Zweiten Weltkrieges," Vierteljahreshefte für Zeitgeschichte, 3 (1973): 325-333; H. von Waldheim, "Les puissances et la politique turco-tatare," Politique étrangère, 3, no. 3 (1938): 236-249. Japan had two protectorates in northeastern China: the State of Manchuria (1932-August 1945) and, in an attempt to coopt Pan-Mongolism, the Mengjiang United Autonomous Government (1939-August 1945).

16 The first, unrecognized, Republic of East Turkestan existed from late 1933 to spring 1934 in southern Xinjiang, more specifically the districts of Kashgar (where its capital was) and Yarkand. Proclaimed and led by Sabit Damullah, it had a more explicitly Pan-Turkic, Sunni Islamic, Jadidist, and anti-Soviet ideological framework. After some five months of shaky existence, it was deposed by the $36^{\text {th }}$ Division of the equally Muslim but ethnically Hui warlord and Guomindang ally Ma Zhongying. For details, see Andrew D.W. Forbes, Warlords and Muslims in Chinese Central Asia: A Political History of Republican Sinkiang, 1911-1949 (Cambridge: Cambridge University Press, 1986), 112-116. 
nature, could somehow inspire and encourage opinion leaders, underground opposition, and population segments among the UssR's Turkic and Tajik population. ${ }^{17}$ And fifth, there was the urge to recover and secure the market for Soviet consumer goods and equipment from the Anglo-American and German firms that had moved into Xinjiang during the Russian Civil War. ${ }^{18}$

Mark Duffield stresses the important role and power of development assistance in securing borderlands and tackling bad externalities. In his opinion, strategic alliances between metropolitan and peripheral states, an important aspect of the former balance of power, lost their geopolitical rationale in the post-Cold War world, and led to a cirsis of state-based security. Rather than enfeeblement and paralysis, however, the crisis of state-based security produced a new security framework based not on the accumulation of arms and external political alliances between states, but on changing the conduct of populations inside them. "Within this new public-private security framework," Duffield says, "stability is achieved by activities designed to reduce poverty, satisfy basic needs, strengthen economic sustainability, create representative civil institutions, protect the vulnerable and promote human rights: the name if this largely privatized form of security is 'development."'19

In Duffield's conceptualization, aid is essentially aimed at changing the conduct of populations in a given area, which also implies promoting preferred models of societal organization and value and norms systems, as well as providing support to local actors who advocate them, whether due to a visionary project, opportunism, or a combination of both. Of course, today's interventionism in that respect is to a large extent multilateral and subcontracted to private or semi-private actors. For its part, Soviet aid to Xinjiang - a threepronged approach consisting of direct and indirect military intervention (officially called "Peace Preservation"), aid aimed at economic rehabilitation and social development, and state-building - was largely bilateral and exclusively involved the state, state-embedded patronage networks, and state-controlled associations or corporations. Multilateral bodies like the League of Nations

17 Shitko, "Voiska OGPU-NKVD v lokal'nykh voinakh i konfliktakh."

18 A more detailed case-based account can be found in Tamara Shemetova, "Iz istorii bor'by Sovetskikh torgovykh organizatsii s inostrannymi firmami za Sin'tsyanskii rynok v seredine 2o-kh gg. xx veka (na primere vaimootnoshenii s Germanskoi firmoi ‘Faist i ke.'), Mir, nauki, kul'tury, obrazovaniya, 33, no. 2 (2012).

19 Mark Duffield, "Governing the Borderlands: Decoding the Power of Aid," Disasters, 25, no. 4 (2001): 310. See also, by the same author, "Social Reconstruction and the Radicalization of Development: Aid as a Relation of a Global Liberal Governance," Development and Change, 33, no. 5 (2002): 1049-1071. 
and the United Nations played no role in the process, and nongovernmental organizations, today a major sub-contractor of aid, hardly existed.

In terms of ideological frameworks and activity sectors, Soviet aid and the actors and institutions through which it was locally channeled, did not put similar emphasis on the human rights ideology nor on artificial civil society, but on the reduction of poverty, the social uplifting of the native masses, the development of tangible social and economic infrastructure, and on socialism and patriotism. The overall situation in Xinjiang was perceived to offer both the momentum and opportunity to implant a friendly alternative through the duplication of (parts of) Moscow's social development, nationbuilding, and Sovietization policies that had just been applied in the CaspianCentral Asian region and in Mongolia. ${ }^{20}$ It was a two-way process, though, in the sense that this could not be done without the co-optation and the active, interested input of local actors and interest groups, especially in areas outside the USSR.

\section{"Frontier Socialism" or Hybrid Governance?}

Local actors and interest groups who become clients are much more than mere sub-contractors or docile administrators. They are most often conscious individuals, networks, and political groups with their own agendas, aspirations, and survival instincts. To realize their diverse aims, they look for external support and often manage to steer the latter to their own advantage or that of their support base. ${ }^{21}$ It is tempting to dismiss Sheng Shicai as yet another sadistic warlord who tyrannized and looted a private fiefdom and its population. While his rule indeed was authoritarian and brutal - traits necessary to survive in Xinjiang back then - and based on personal patronage networks, it went well beyond mere exploitation or greed. In that respect, he reportedly differed from his immediate predecessor. In his detailed political portrait of the man, Fook-Lam Chan describes Sheng Shicai as a convinced Chinese

20 For a detailed account of the nationalities and social transformation policies in the Caspian-Central Asian region of the UssR, see Olivier Roy, La nouvelle Asie centrale, ou la fabrication des nations (Paris: Seuil, 1997): 93-136.

21 In the case of Sheng Shicai, Stalin and his delegates in Moscow were well aware of this, as is reflected in Stalin's castigating 1934 note to his consul-general in Ürümçi mentioning Sheng Shicai's "desperate Leftism." RGASPI, letter of July 27, 1934, from Stalin to Garegin Apresov, consul-general in Ürümçi, http://digitalarchive.wilsoncenter.org/ document/121898. 
nationalist who considered Xinjiang province to be a permanent part of the motherland. ${ }^{22}$

Besides nationalism and patriotism, his ideological framework consisted of leftist-socialist ideas and a strong anti-Japanese stance, both of which were rooted in the conviction that China's social and economic stagnation were due to imperialist exploitation and the domestic forces that helped to sustain it. ${ }^{23}$ Much of this is believed to have been shaped by personal experiences in his native Liaoning province, during his stay at the Imperial War College in Japan in 1925, and while he served, in the 1927-1929 period, in Feng Yuxiang's Sovietbacked Guominjun (Nationalist Army), a leftist-nationalist faction that was active in Liaoning during the warlord era and that supported the Guomindang government. ${ }^{24}$ Also, at the time, Stalin's USSR and its development approaches were not yet associated with the horrors of the labor camps and the collectivization disaster, as they commonly are today.

Instead, the Soviet Union's perceived economic and social achievements, viewed alongside the Great Depression, raised not a few hopes and expectations for a more just order of things among leftists (not only Soviet-aligned communists) worldwide, not only in China but also in India, Iran, Western Europe, and the Americas. During the period under examination, the Communist Party of China was just beginning to gain some foothold in Xinjiang. A "StalinistSoviet Xinjiang" accompanied by the creation of modern nationalities and social transformation similar to that which had occurred in the Caspian-Central Asian and Caucasian parts of the USsR could thus be a social laboratory for the societal model its champions hoped to expand to other parts of China, once the country stabilized and became functional again.

22 Fook-Lam Gilbert Chan, "Shen Shih-Ts'ai's Reform Programs in Sinkiang: Idealism or Opportunism?” Bulletin of the Institute of Modern History - Academia Sinica, no. 12 (1983): $365-384$.

23 Ibid.

24 Called Fengtian between 1907 and 1929, what is now Liaoning province was part of an area under informal and alternating Russian and Japanese influence since about 1875 . After having defeated China in the 1894-1895 war, Japan claimed the Liaodong peninsula. Yet, in 1898, Russia was granted a concession over it. With Russian and Japanese assistance and capital, parts of the province were industrialized and thus confronted with corresponding sociological changes. In 1896-1903, it was connected to the Russian railroad system with the construction of the Eastern Railway between Port Arthur and Harbin. Many major battles in the Russo-Japanese War of 1904-05, including these of Port Arthur and Mukden, took place in the area. Eventually, Liaoning was invaded by Japan in 1931 and incorporated the following year into the State of Manchuria, of which it remained part until 1945 . 
Since the number of fellow Han and Hui was relatively limited in Xinjiang and even fewer would be considered reliable or loyal to him, Sheng Shicai wanted to build a support base among the native Turkic majority. It was not all about political calculations, however. As a visionary outsider, Sheng Shicai reportedly also had a sincere fascination for his jurisdiction's beautiful landscapes and native population and was thus also driven by an idealistic urge to uplift the latter though a project of "Inclusive Patriotism." In summer 1934, he and his advisors elaborated an eight-point declaration for a project of "Xinjiang Renewal." The declaration stressed the imperative to create equality among races; establish religious freedom; provide rural relief; implement financial, administrative, and judicial reforms; expand education; and introduce local self-government.

This was soon followed by the "Nine Chief Duties" declaration, a sort of priority action plan that included eradicating corruption, economic and cultural development, maintaining peace, mobilizing manpower for land cultivation, improving communications infrastructure, preserving Xinjiang as a part of the republic of China, fighting imperialism through a close alliance with the USSR, reconstruction work, and protecting the freedom and privileges of religious leaders. ${ }^{25}$ These declared duties, along with the state in Xinjiang, structured Soviet aid to Sheng Shicai's governorate. So, what characterized the governorate in terms of state and governance structures? Although nominally the province was part of the republic of China, it was functionally independent. The quasi state and its governance structure had basically four components.

First, there were Sheng Shicai's inner circle and personal networks, most of whom were Han or were originally from Liaoning. This was a highly diverse group that included close relatives such as his wife, Qiu Yufang, and father-inlaw, long-time allies with similar interests or who were sympathetic to his reform program, upper-level members of the provincial bureaucracy who also had economic interests in the province, and a number of Guomindang cadres and Chinese communists. ${ }^{26}$ His inner circle would play a particularly prominent role during the decline of his regime after 1941-1942.

25 Chan, “Shen Shih-Ts'ai's Reform Programs in Sinkiang, 375.

26 The UssR's active backing of Sheng Shicai was not meant to be against the Guomindangdominated government of Nanjing, nor did Moscow cut ties with the latter. It rather accommodated the reality of weak central control within the Chinese great space and the local circumstances in Xinjiang at that time. Although the USSR did not engage in overt war with Japan until the summer of 1945, it concluded support agreements with the Guomindang government in 1938 with some $\$ 200$ million of loans and in-kind assistance to help it contain Japanese expansion. See also Mirovitskaya, "Kitaiskaya provintsiya Sin'tszyan v Sovetsko-Kitaiskikh otnosheniyakh (1930-1940)," 244. 
Second, although he adhered to the Communist Party of the Soviet Union in early 1938 and despite his close alliance with the USSR, Sheng Shicai did not set up a Xinjiang branch of the Soviet Communist Party nor any similar unitary party for that matter. Instead, the politicization and propaganda work was carried out through the Anti-Imperialist League, which he founded in summer 1935 and reportedly had some 10,00o Han, Hui, and Turkic members by $1939 .{ }^{27}$

Third, Soviet personnel stationed in Xinjiang were crucial for the functioning and survival of his regime and for the planned development of state and society. This group was accountable to the Soviet consulate-general in Ürümçi and consisted of three broad categories. First, there were civilian governance and economic advisors and the technicians - today's development workers and consultants - who had been assigned to Sheng Shicai's cabinet, ministries, and a wide range of Soviet-supported economic and social infrastructure projects beginning in spring 1935. The exact overall number of Soviet advisors and technicians who worked in Xinjiang between 1935 and 1942 is not well documented, but there were likely several thousand. ${ }^{28}$ Many were of Slavic background, but others belonged to Central Asian Turkic groups including Soviet Uyghurs as well as some Han and Hui naturalized Soviet citizens. ${ }^{29}$

Second, there was the 3,000-strong Soviet regiment and one air squadron that had been stationed near Kumul in the wake of the Soviet military interventions to prop up Sheng Shicai in early 1934 and again in mid-1937, after the Japanese invasion of China. These included Soviet military advisors who equipped and trained Sheng Shicai's 10,000-strong army. The latter consisted mostly of provincial Guomindang units, local militias, and some 1,80o Soviet and White Russian cavalry. ${ }^{30}$ Finally, there were the staff and the paramilitary

27 Fook-Lam Gilbert Chan, "Shen Shih-Ts'ai's Reform Programs in Sinkiang," 373, 378 and 381.

28 One account mentions more than 1,00o "Soviet technicians" in two districts situated between Ürümçi and the Mongolian border alone, yet this is unlikely to reflect an province-wide pattern because the northern portion of Xinjiang at areas used indeed to be a focal area for Soviet development assistance work. Li Chang, "The Soviet Grip on Xinjiang," Foreign Affairs, no. 4 (1954): 499.

29 Wang, "Soviet Citizenship in Xinjiang," 88-89.

30 In fall 1935, a loan of 2 million gold rubles was allocated for the upgrading the Xinjiang army. Communist Party of the Soviet Union, Politburo minutes of September 13, 1935, RGASPI, f. 17. op. 162, d. 18, l. 141-142, http://digitalarchive.wilsoncenter.org/document/ 121853 Stalin himself and his Defense Commissar Voroshilov seemed to have had a preference for a provincial army dominated by Han officers and rank-and-file, probably so as not to have too many armed and military-trained Turkic soldiers who were deemed unreliable and may become dangerous in case of mutinies. "Beseda tov. Tov. Stalina, Molotova 
of Stalin's secret police, the NKVD. ${ }^{31}$ Besides running intelligence networks in the province, closely watching émigré communities from the USSR, and following up on real and perceived anti-Soviet activities there, the NKVD assisted Sheng Shicai's Governorate in setting up and training its fourth component, the Baoan budui (Security Preservation Corps) in 1936. The Baoan budui coopted, among others, the extensive informants' networks set up under Yakub Beg's emirate of Jetışar ("Seven Cities"), which existed in southwestern Xinjiang and was ruled from Kashgar between 1867 and $1877 .{ }^{32}$

The presence of this fourth network reveals that the Governorate actively co-opted native interest groups and informal institutions to build a proper base for his societal project among the local majority population. ${ }^{33}$ Sheng Shicai was quite serious about participation and local self-government in that respect. To start with, province-wide consultations were organized in Ürümçi in the spring 1935 and 1936, and again in fall 1938, to which Uyghur, Kazakh, and other native leaders were invited. This also included offering government positions to members of the Khoja religious aristocracy whose authority was based on claimed descent from the prophet Muhammad or the first four Arab caliphs and of the Chagatai Mongols and on institutions established during the rule of a Khoja confederation over much of present-day Xinjiang between 1678 and 1759. Although Soviet-inspired secularization campaigns would be attempted under the influence of his advisors, Sheng Shicai seemed to understand the strong social role of Islam, specifically the Kubrawiyya and Nakhsh'bandiyya Sufi networks, among the Turkic and Hui population and the need to secure their backing to gain the support of the native majority.

i Voroshilova s dubanem, proiskhodivshaya v Kremle 2.9.1938," RGASPI, f.558, op. 11, d. 323, l. $3^{2-41, ~ h t t p: / / d i g i t a l a r c h i v e . w i l s o n c e n t e r . o r g / d o c u m e n t / 1219 o 1 . ~}$

31 A detailed overview of in-kind means allocated in early 1938 to the NKVD to set up a 1,570-strong motorized regiment in Hami (Kumul) and to train and equip the local police force there was found in the minutes of the Politburo of the Communist Party of the Soviet Union of 21 January 1938, RGASPI, f. 17, op. 162, d. 22, http://digitalarchive .wilsoncenter.org/document/121877 Besides 15 tanks, the list contains 55 ZIS- 5 trucks, 30 petrol trucks, two ambulances, four vehicle repair workshops, 1,025 horses, three radio vehicles, and, interestingly, two film production units that were certainly meant to serve what today would be called "public diplomacy" or "PR." Lars-Erik Nyman, "Sinkiang 1934-1943: Dark Decade for a Pivotal Puppet," Cahiers du Monde russe, 32, no. 1 (1991): 100.

33 Similar co-optation processes of local power groups and solidarity networks took place during the creation of nationalities and the social transformation among the Turkic and Tajik peoples in the Central Asian and Caspian parts of the Soviet Union. For a detailed examination, see Roy, La nouvelle Asie centrale, 93-139. 
He thus basically "recycled" a practice of indirect rule that had been set up in the imperial era around 1760 , in which China's political authority, especially in southern Xinjiang, was based on the co-optation of Khoja and Sufi networks as well as on the Chinese military garrisons and trade posts that were established near the region's main urban centers. ${ }^{34}$ Sheng Shicai was also supported by the pro-Soviet Kyrgyz of Ishaq Beg in the southwestern Ulugqat region, and he awarded local and provincial government posts to a dozen Uyghur leaders of the 1931 Kumul and Kashgar rebellions - like Hoja Niaz and Yulbars Khan after they were pardoned upon officially renouncing separatism. Finally, in his efforts to boost education, some elements of the Pan-Turkic Jadid education reform movement who had played an active role in the first East Turkestan republic of Kashgar were also integrated in the policies geared toward the renewal of Xinjiang. ${ }^{35}$

\section{Components of Soviet Aid to Xinjiang}

In 1931, under Sheng Shicai's predecessor, 82.5\% of Xinjiang's official external trade occurred with the UssR. Between 1933 and 1936, the official value of Soviet imports from Xinjiang amounted to some 66 million gold rubles, while exports from the USSR into the province approached 102 million. Much of this trade happened on a barter basis and was organized and controlled by the Soviet-Xinjiang Trading Company, which was established in 1931 under Governor Jin Shuren and operated six agencies in the province. Overall, Xinjiang was the UssR's ninth-largest trading partner that year, and the fourthlargest non-European partner after China proper, Mongolia, and Iran. During that period, formal trade between the province and the rest of China was close to nonexistent, although there was certainly informal trade with neighboring Gansu province, as well as cross-border trade with Mongolia and with Leh and Gilgit in northern India. In 1935 and 1937, the UssR gave two loans, each worth

34 For an in-depth examination of this system of frontier control, see Kwangmin Kim's dissertation, "Saintly brokers: Uyghur Muslims, trade, and the making of Qing Central Asia, 1696-1814" (Berkeley: University of California, 2008); Elisabeth Allès, "Usages de la frontière: le cas du Xinjiang (xIxe-Xxe siècles)," Extrême-Orient, Extrême-Occident, - Desseins de frontières, no. 28 (2006): 127-146 and Owen Lattimore, Studies in frontier history - collected papers 1928-1958 (London: Oxford University Press 1962), 197.

35 Eric T. Schluessel, "History, Identity and Mother-Tongue Education in Xinjiang," Central Asian Survey, 28, no. 4 (2009): 390. 
7.5 million gold rubles, to the Xinjiang governorate. ${ }^{36}$ The pattern of SovietXinjiang development cooperation was thus set by intensive commercial interaction, preferential trade agreements, and state loan dependency. ${ }^{37}$

Although some development work was done in the southern oases of Kashgar, Yarkand, and Khotan, much of the Soviet-backed efforts during the Sheng Shicai years were concentrated in and around Kulja, Ürümçi and the belt around and between those two centers. These northwestern parts of Xinjiang were quite accessible and considered sufficiently secure to permit sustainable investment. More important, they were also part of a larger historical Russian economic sphere and regarded as having an ethnically mixed population that could generate a modern proletarian base that could eventually support a larger socialist project. In turn, it was assumed that development in this geographic area would entice more remote or socially and politically more recalcitrant parts of the province to follow suit.

Moscow organized immediate humanitarian assistance meant to alleviate the consequences of armed conflict that affected Xinjiang between 1931 and 1933. Officially called "economic stabilization aid," this assistance was partly attached to loans, other settlement agreements, or meant to open markets. In the summer of 1934, for example, the Soviet Union reportedly sent 1,450 tons of wheat to Xinjiang and committed 1,00o additional tons of grain if harvests did not meet expectations. In addition to grain, the aid included other commodities intended to stabilize the province and return to productivity. In early 1934, a shipment of 250 tons of sugar, 22 tons of brick tea, 50 tons of kerosene, and 100 tons of rice were also readied for import into Xinjiang. ${ }^{38}$ The USSR also provided highly securitized assistance to refugees who had fled factional fighting in Xinjiang and often arrived in the Kazakh ASSR, especially in the province of Semipalatinsk and in the district of Jarkent. ${ }^{39}$ Given the security concerns

${ }_{3} 6$ David D. Wang, Under the Soviet Shadow: The Yining Incident, Ethnic Conflicts and International Rivalry in Xinjiang, 1944-1949 (Hong Kong: The Chinese University Press, 1999), 54. Other accounts put the 1935 and 1937 Soviet loan packages to Xinjiang at 5 and 8.76 million gold rubles, respectively. Yu Guan, "Shtrikhi k politicheskomy portrete Shen Shitsai," Vostokovednye issledovaniya, no. 4 (2004): 124.

37 In Ürümçi, in the areas of Xinjiang bordering the UssR, and in trade circles, the Soviet ruble circulated as the de facto currency. This is quite reminiscent of the similar position that the euro and dollar have in neo-protectorates like Kosovo, Bosnia, and East Timor.

38 Judd Creighton Kinsley, “Staking Claims to China's Borderland: Oil, Ores, and State Building in Xinjiang Province, 1893-1964 (San Diego: University of California, 2012), 182. This unpublished doctorate thesis is based on many Chinese-language sources.

39 Jarkent in Kazakhstan (also spelled Zharkent, and called Panfilov between 1942 and 1991) should not be confused with the city and oasis of Yarkand in southern Xinjiang. 
that refugees raised - especially that anti-Soviet elements might infiltrate among them - the NKVD, not international refugee agencies or specialized charities, organized the assistance and registration effort. In 1935, for example, 1.2 million rubles were allocated to the NKVD for the purpose of accommodating "Xinjiang arrivals." 40

The first tranche of the 1935 loan of 5 million gold rubles to the Ürümçi government (URPRA) was allocated as follows: one-quarter ( 1.25 million) was to be spent on transport and communications, and one-third (1.65 million) on light industry and agricultural credits. Further, 350,000 ( 7 percent) was budgeted for extractive activities (tin mining and the construction of an oil refinery), 10 percent (500,00o rubles each) to purchase silver to shore up the Xinjiang Provincial Bank and military equipment, another 700,00o rubles for non-specified "materials earlier provided to URPRA" (possibly weapons, vehicles, or even office equipment for URPRA administrative institutions), and finally one percent, or 50,000 rubles, for health care infrastructure. ${ }^{41}$

This snapshot clarifies the priority areas for Soviet aid to Xinjiang throughout the Sheng Shicai period. One was the delivery of engineering assistance, construction machinery, trucks and tractors and, for the year 1935-1936, some 600,000 rubles for building or upgrading roads. Although Soviet-led construction brigades carried out road projects in the south, particular importance was attached to some 3,200 kilometers of road connections in the northwest. More specifically, these included the road between Jarkent in the Kazakh (A)ssR, Kulja, Ürümçi and eventually Kumul, as well as the road between Ürümçi and the district of Urjar in Kazakhstan. Soviet advisors also created and co-staffed a governmental Road Committee that had to organize and oversee the maintenance and securitization of these transport arteries. ${ }^{42}$ The technical cadres and most foremen of the work brigades were Soviet citizens. For the unskilled work on these labor-intensive road projects, however, they attempted to recruit native Ili and other Uyghurs and Kazakhs.

To an extent, this was a repeat of a social experiment carried out, with varying impact, during the construction of the Turksib Railway in the Kazakh (A)ssR a few years earlier. The unstated purpose of that experiment had been

\footnotetext{
40 Communist Party of the Soviet Union, Politburo minutes no. $3_{2}$ from 31 July to $3_{1}$ August 1935, RGASPI, f. 17. op. 162, d. 18, l. 105, http://digitalarchive.wilsoncenter.org/document/121851.

41 Communist Party of the Soviet Union, Politburo minutes no. 23 of March 22, 1935, attachment to point $178(\mathrm{OP})$, Prilozhenie No. 1 "Raspredelenie tovarnoi ssudi Sovsintorga," http://digitalarchive.wilsoncenter.org/document/121828.

42 Vasilii Shmatov, “Rol' Sovetskogo Soyuza v 'ozdrovlenii' sotsiyal'no-ekonomicheskoi zhizni provintsii Sin'tszyan (1934-37)," Mir nauki, kul'tury, obrazovaniya, 43, no. 6 (2013): 445.
} 
to recruit young Kazakh shepherds for menial work on the wharfs in order to detach them from traditional authorities and modes of production and turn them into the nucleus of a native proletariat. The concentration of mainly young native men on work sites was also a good opportunity to hold political meetings. ${ }^{43}$ Soviet-Xinjiang development cooperation also focused on electrification and improving communication facilities in the province, although a postal and telegraph system already existed. Between 1934 and 1937, Soviet technicians installed new power stations and telephone switchboards in Ürümçi and Kulja, at a combined cost of 130,665 gold rubles. ${ }^{44}$ Some 2,100 kilometers of telephone lines were reportedly installed during the governorate. ${ }^{45}$

\section{Hinterland Industrialization}

A third area of development cooperation was industrialization. This included both extractive and light-processing industries, which seemed to be driven by two different, yet complementary, rationales. In the extractive sector, there were basically three core activities. First, from 1936 onward, Soviet personnel developed the Dushanzi (Maitağ in Turkic) oil fields, which had been discovered in 1909. In 1939, 33 wells were drilled and 17 became operational. A refinery was also built. Although developing Xinjiang's oil industry was initially not a priority for Moscow, concern that the USSR would eventually be dragged into a war in Europe, and that the Carpathian and Caspian oil production centers could be occupied if not destroyed, gave a new boost to oil-related assistance to the province. By 1942, the UssR's investment in Xinjiang's oil industry at Dushanzi was estimated at $\$ 3$ million.

Also in 1942, $15^{8}$ Soviet engineers, technicians, and foremen, many of them with previous experience in the Baku oil fields, were employed in this sector. ${ }^{46}$ That spring, the joint refinery operations were formalized with the creation of the Soviet-Xinjiang Company for the Dushanzi Oil Combinate Exploitation, a management structure, and an inter-governmental $50 / 50$ profit-sharing agreement. ${ }^{47}$

43 Matthew J. Payne, Stalin's Railroad: Turksib and the Building of Socialism (Pittsburgh, PA: University of Pittsburg Press, 2001), especially 131-137.

44 Vasilii Shmatov, "Rol' Sovetskogo Soyuza v 'ozdrovlenii' cotsiyal'no-ekonomicheskoi zhizni provintsii Sin'tszyan (1934-37)": 445 .

45 Chan, "Shen Shih-Ts'ai's Reform Programs in Sinkiang": 379.

46 Kinsley, "Staking Claims to China's Borderland": 234-235.

47 Communist Party of the Soviet Union, Politburo minutes no. 36 of April 26, 1942, RGASPI f. 17 op. 162 d. 37, l.33-34, http://digitalarchive.wilsoncenter.org/document/121886. 
Second, in 1937, 2 million rubles and \$40,00o were allocated for geological exploration of non-ferrous metals deposits. In fall 1940, 30-year concessions in the Ili Valley, close to the border with the Kazakh ssR, were granted to the joint-stock Xinjiang Tin Company to extract tin for the Soviet aircraft and cannery industries. At its zenith, about 60 Soviet engineers and technical cadres were employed on this line. ${ }^{48}$ Third, gold mining in the Altai piedmont was upgraded with Soviet assistance. About 20 Soviet engineers and technicians were employed here along with mainly Hui and Kazakh workers. ${ }^{49}$ The fact that the USSR's monetary system was on the gold standard at the time, officially to limit its dependency on the international monetary system and on the dollar, and that the USSR used gold to trade with Western Europe, explains the importance that Moscow attached to this specific extractive activity.

So, cooperation with Xinjiang seemed mainly geared toward the creation of a classical economic hinterland - or even a raw material periphery - for the USSR, rather than a proper industrialization drive. Simultaneously, however, efforts were also invested in light industry. In 1941, for example, the USSR funded 11 factory projects - sugar, matches, candles, paper, cement, wool and linen, tobacco, soap, and a cannery - mainly in Ürümçi and Kulja. ${ }^{50}$ These projects had political goals as well. Accelerated and state-initiated industrialization and the formation of an industrial proletariat were considered a necessary pre-requisite for socialism as well as for economic and military independence. ${ }^{51}$ So, Moscow's multisectoral assistance to Sheng Shicai's Xinjiang contained an element of social engineering. One key industrial project set up in 1938, once the province had become a land corridor (the so-called Zeta track) for Soviet aid to the Guomindang government after the Japanese invasion of China in 1937, was an aircraft assembly factory. Part of a $\$ 200$ million assistance package to the national Chinese government to help it to fight the Japanese, the factory was initially planned for eastern Gansu but was eventually built on the outskirts of Ürümçi at Stalin's insistence. ${ }^{52}$

48 Kinsley, "Staking Claims to China's Borderland," 232-234 and Communist Party of the Soviet Union, Politburo minutes no. 45, RGASPI F.17 op. 162, d. 20 l.181, http://digitalarchive .wilsoncenter.org/document/121873.

49 Kinsley, "Staking Claims to China's Borderland."

5o Vasilii Shmatov, "Rol' Sovetskogo Soyuza v 'ozdrovlenii' cotsiyal'no-ekonomicheskoi zhizni provintsii Sin'tszyan (1934-37)," 446.

51 Basile Kerblay, "L'impact des modèles « économiques » soviétiques et chinois sur le Tiers Monde," Politique étrangère, 25, no. 4 (1960): 336.

$5^{2}$ Vasilii Shmatov, “'Sovetskie kryl'ya' kitaiskoi aviyatsii (o stroitel'stve i deyatel'stve i deyatel'nosti aviasbornogo zavoda v Sin'tszyane v 1938-1941 gg," Izvestiya Altaiskogo Gosudarstvennogo Universiteta, 80, no. 4 (2013): 97-100. For an elaborate account on 
Depending on social geography, the indigenous Turkic population either practiced varied oasis agriculture geared toward local and micro-regional markets and using ancient and sophisticated irrigation systems; nomadic or seminomadic animal husbandry; or hybrid forms of both. In contrast, the sedentary Hui and Han farmers in the province, especially in the north, were relative newcomers. Sheng Shicai placed great importance on agricultural development, in hopes that his subjects would produce commodities like cotton, grain, and leather for lucrative export that could fill state coffers as well as enrich companies owned by members of his entourage. ${ }^{53}$ It was also an activity and sector for which he had a personal fascination. This initially translated into the provision of immediate relief, in the form of sheep, cattle and seeds, to farmers who had been affected by political unrest and in the opening of soft credit lines for farmers at the State Bank. ${ }^{54}$

He also curbed the extortive agricultural tax practices used by former governors, local civil servants and co-opted local rulers. Most important, he did not launch a Soviet-style agricultural collectivization campaign. In fact, parts of his jurisdiction were struggling to accommodate tens of thousands of Kazakh and (to a lesser extent) Mongol herders and Soviet Hui farmers who had fled the USSR and Mongolia following the disastrous collectivization drives there. ${ }^{55}$ The initial slump in agricultural production caused by collectivization actually gave a boost to agriculture in Xinjiang, in the sense that the province became an exporter of cattle and cotton to the USSR - much of it through Semipalatinsk - to meet shortages there. The governorate undertook a number of major agricultural initiatives, such as opening veterinary clinics and outreach centers where farmers could get access to new technologies and crop varieties and state-backed agricultural loans.

It also assigned military and paramilitary units and native labor brigades to state-sponsored land reclamation and irrigation projects. ${ }^{56}$ Soviet aid was instrumental to these projects. In late 1935, for instance, the Commissariat for

Xinjiang's function as a cockpit and corridor for Soviet assistance to the Guomindang and the Chinese communists, see John W. Garver, Chinese-Soviet relations 1937-45: The Diplomacy of Chinese Nationalism (New York: Oxford University Press, 1988), 153-181.

53 For an examination of the rural development paradigm and the impact of the Soviet development model on it, see Alastair McAuley, "La politique de développement en Asie centrale: réflexions sur les possibilités de l'appliquer aux pays voisins du Moyen-Orient," Revue d'études comparatives Est-Ouest, 15, no. 4 (1984): 5-30.

54 Chan, "Shen Shih-Ts'ai's Reform Programs in Sinkiang," 375-376.

55 Wang, "Soviet Citizenship in Xinjiang."

56 Calla Wiemer, "The Economy of Xinjiang," in S. Frederick Starr (ed.), Xinjiang: China's Muslim Borderland (London: M.E. Sharpe-Central Asia-Caucasus Institute, 2004), 167. 
TABLE 1 The Evolution of Agricultural Productivity in Xinjiang According to Selected Indicators (1918-1949)

\begin{tabular}{llrll}
\hline & $\begin{array}{l}\text { Cultivated land } \\
\text { (in 1,0oo hectares) }\end{array}$ & $\begin{array}{l}\text { Grain } \\
\text { (in 1,00o tons) }\end{array}$ & $\begin{array}{l}\text { Cotton } \\
\text { (in 1,ooo tons) }\end{array}$ & $\begin{array}{l}\text { Cattle herds } \\
\text { (in million heads) }\end{array}$ \\
\hline 1918 & 802 & 2,061 & 10.5 & 18.4 \\
1933 & 309 & 695 & 10.6 & $5 \cdot 4^{*}$ \\
1942 & 996 & 1,761 & 14.2 & $19 \cdot 7$ \\
$1949^{*}$ & $373^{* *}$ & 848 & $5 \cdot 1$ & 10.4 \\
\hline
\end{tabular}

Notes:

* 1931 value.

** This was the realistically cultivated part of the 1.2 million hectares of arable land area at that time. In our opinion, this sharp decrease is also explained by the fact that parts of Xinjiang were under the second East Turkestan Republic and not under provincial administration at that time, by the decrease of Soviet assistance and that much land remained fallow during the late Sheng Shicai period (1943-1944) and the Guomindang interregnum between his departure and the final communist takeover of Xinjiang in 1949.

Sources: Table based on Calla Wiemer, "The Economy of Xinjiang," in S. Frederick Starr (ed.), Xinjiang: China's Muslim Borderland (London: M.E. Sharpe-Central Asia-Caucasus Institute, 2004), 167. See also Judd Creighton Kinsley, "Staking Claims to China's Borderland: Oil, Ores, and State Building in Xinjiang Province, 1893-1964 (San Diego: University of California, 2012), 289.

Agriculture in Moscow, despite the ongoing agriculture crisis caused by collectivization in the USSR itself, reportedly offered reapers, sowing machines, agricultural tools, variety seeds, breeding cattle and other equipment for a total value of 260,000 rubles. Likewise, it provided support to a number of agro-industrial projects like a cotton ginnery, a vegetable oil mill, and a sawmill in Ürümçi. ${ }^{57}$ Table 1 shows the clear rises in agricultural productivity during the Sheng Shicai years.

\section{Social Transformation and Nationalities}

Finally, education plays a key role in borderland development approaches that include social engineering, by instilling the appropriate norms, values, and ideology. In the broader sense, efforts in education were embedded in a project of nation-building and social transformation. In 1934, Sheng Shicai recognized 14 officially equal ethnic communities or nationalities of Xinjiang. In doing so, he

57 Shmatov, "Rol' Sovetskogo Soyuza v 'ozdrovlenii' cotsiyal'no-ekonomicheskoi zhizni provintsii Sin'tszyan (1934-37)," 446. 
and his nationalities committee drew heavily from the nationalities criteria in use right over the border in the UsSR. According to Olivier Roy, these had basically three components: (1) a theoretical foundation on the concept of the nation - elaborated by Stalin or at least attributed to him - that was eclectically based on Marxist concepts and on nineteenth- and early twentiethcentury Russian and Western European anthropology; (2) an administrativepolitical classification based on the status of territory and language; and (3) a pragmatic approach to national delineation that took into account local realities, yet justified itself with the first two components. ${ }^{58}$

The creation of modern nations, based on historical or aspired identities, different censuses, ethnography, and even recycled concepts championed by Turkic nationalist intellectuals and activists had to counter transnational ideologies like Pan-Turkism and Sunni Islam in order to create the basis for socialism. Sheng Shicai's recognition of 14 nationalities was a clear break from Guomindang's "Five Great Races under one Union” approach, which he, as a Guomindang-affiliated official, was supposed to follow. The "Five Great Races" formulation excluded Turkic people, who made up a considerable portion of Xinjiang's population.

Thus for the first time, the sedentary Turkic population, with its plethora of micro-regional and local identities, was officially included under the common denominator of "Uyghurs."59 For Sheng Shicai, this recognition was a key element of his inclusive patriotism, since for him, they were all children of Xinjiang. Furthermore, since he regarded the region as an unalienable part of the Chinese great space, this meant they were also children of China. ${ }^{60}$ However, his advocacy of local self-government did not include establishing a federation of nominally autonomous national republics and territories in Xinjiang, as was done in the UssR. A structure of this type was only set up in 1949-1958, after the communist takeover of the province. ${ }^{61}$ The next step after

58 Roy, La nouvelle Asie central, 108; Olivier Roy, "Ethnies et politique en Asie centrale," Revue du monde musulman et de la Méditerranée, no. 59-6o (1991): 24-27.

59 Note that initially, Uyghurs and Uyghurs from the Ili region (whose culture and society were distinct from the Uyghurs from the oases of southern Xinjiang and from Kumul because of their interaction with the Russian sphere since the 185 os and because of the Ili region's role as a Sino-Russian frontier) were considered two separate national groups. See also Sean D. Roberts, "Imaging Uyghurstan: Re-evaluating the Birth of the Modern Uyghur Nation," Central Asian Survey, 28, no. 44 (2009):364-366. Other recognized groups included Uzbeks, Tatars, Kyrgyz, Kalmyk and Torgut Mongols, and Sibe.

6o Ondřej Klimeš, Struggle by the Pen - The Uyghur Discourse of Nation and National Interest, c.19oo-1949 (Leiden: Brill, 2015), 164-165.

61 Bergère, "Linfluence du modèle soviétique sur la politique des minorités nationales en Chine. La cas du Sinkiang (1949-1962)," op. cit., 1979: 414-420. 
recognition was to codify and modernize Turkic national languages by providing them with a script; by limiting "alien" Arabic, Farsi, and Islamic terms; and by incorporating Russian and Chinese technical, bureaucratic, and military terminology. ${ }^{62}$ The modern Uyghur language thus came officially into being.

As in the USSR, the national languages became the vehicles to educate a mostly illiterate population. Learning Russian and Chinese, which de facto became vectors of social progress, was also encouraged, just like learning Uyghur or Kazakh was encouraged among Han and Hui, at least traders, civil servants, officers, and other people who frequently came into contact with the Turkic population. Likewise, the provincial governmental newspaper, The Xinjiang Daily, an important mouthpiece of the Ürümçi Governorate, was published in seven languages and produced and distributed through nine regional hubs. With Soviet backing, the state tried to take the lead in an education sector that had long been closely connected to religious institutions, skills and knowledge transfer within genealogical solidarity networks, nongovernmental education movements, or private educational entrepreneurship, all of which continued to function in some form or capacity. ${ }^{63}$

In that respect, three prominent channels of state-supported education appeared between 1934 and 1939. First, the secular provincial schools under the provincial education department. These schools, particularly concentrated in the north, were government-sponsored and partly based on the secular nationalist education system that the Guomindang promoted and tried to organize, conditions and resources permitting, in the areas under its control. With Soviet backing, Sheng Shicai's regime managed to set up a more extensive version of this system in its jurisdiction. ${ }^{64}$ The Xinjiang Provincial Russian Law School, which had been founded with Soviet assistance in Ürümçi in 1924 and was already an important channel of Soviet political and cultural influence before Sheng Shicai's arrival, was upgraded to a Provincial University College in 1935 and became the province's first higher learning institution, although its staff and students would remain predominantly Han. ${ }^{65}$

62 Klimeš, Struggle by the Pen, 172-173 and Roy, La nouvelle Asie central, 124.

63 See Ildikó Bellér-Hann, Community Matters in Xinjiang 2008: 326-333 and Eric T. Schluessel, "History, Identity, and Mother-Tongue Education in Xinjiang," Central Asian Survey, 28, no. 4 (2009): 384-389.

64 Gerard A. Postiglione, China's National Minority Education: Culture, Schooling, and Development (New York: Falmer Press, 1999), 27-28.

65 Anthony R. Welch and Ruy Yang, "Internationalizing a Regional Chinese University," in John D. Palmer, Yong Ha Cho, et al. (eds), The Internationalization of East Asian Higher Education: Globalization's Impact (London: Palgrave-Macmillan, 2011), 71-72. 
Second, a network of independent but government-subsidized schools was organized under various Cultural Promotion Societies or CPS. Established for nine of the 14 recognized nationalities between 1935 and 1939, the CPS were initially a governorate attempt to co-opt, under the auspices of the AntiImperialist League, the variety of privately sponsored schools that had been previously established among Uyghurs and Uzbeks by modernist and Islamic educators. ${ }^{66}$ The idea to use rather than outlaw these schools reportedly came from Soviet advisors who understood that bluntly imposing unpopular Chinese or secular institutions would be counterproductive. Hence, using existing native networks was believed to be a more effective way to promote education, especially in the more recalcitrant southern portion of the province.

The first Uyghur CPS were founded in Kashgar and Kulja. They operated autonomously but received financial and in-kind support, such as textbooks, from the Provincial Education Department. Their activities went well beyond education and included the management of private donations and Islamic endowments, opening cinemas and theatres, and running housing and urban maintenance projects. ${ }^{67}$ To carry out these public works, the CPS and the governorate often used (or, as some felt, usurped), the traditional institution of alwang, collective labor that resembles feudal corvée service, which was prevalent in Uyghur society. ${ }^{68}$ Surprisingly, the CPS were also involved in trade with the USSR, more specifically collection and retail centers. ${ }^{69}$ As can be seen in Table 2, these CPS school networks became the nucleus of the governorate's education system.

Third, there were educational exchanges with the UsSR. Soviet advisors trained civil servants and technicians in Xinjiang itself, or students from Xinjiang were sent to the USSR for higher education. Between 1934 and 1937, 586 students from Xinjiang went to Tashkent, Alma-Ata, and Chimkent to study medicine, agriculture and animal husbandry, educational pedagogy, and public administration. Others attended political training at universities and technical colleges there. Of the 106 exchange students sent in 1934, 63 were Uyghur, 33 Han, 4 Hui, 2 Kazakh, and 2 belonged to one of the Mongol peoples. The following year, 100 students were sent to the UssR, including 54 Uyghur

66 Ildikó Bellér-Hann, Situating the Uyghurs between China and Central Asia (Farnham: Ashgate, 2007), 166-167.

67 Schluessel, "History, Identity, and Mother-Tongue Education in Xinjiang," 390-392.

68 Bellér-Hann, Community Matters in Xinjiang., 2008: 171-175; Ildikó Bellér-Hann, "Work and Gender among UyghurVillagers in Southern Xinjiang," Cahiers d'Etudes sur la Méditerranée Orientale et le monde Turco-Iranien, no. 25 (1998): 2-5.

69 Schluessel, "History, Identity, and Mother-Tongue Education in Xinjiang," 390-392. 


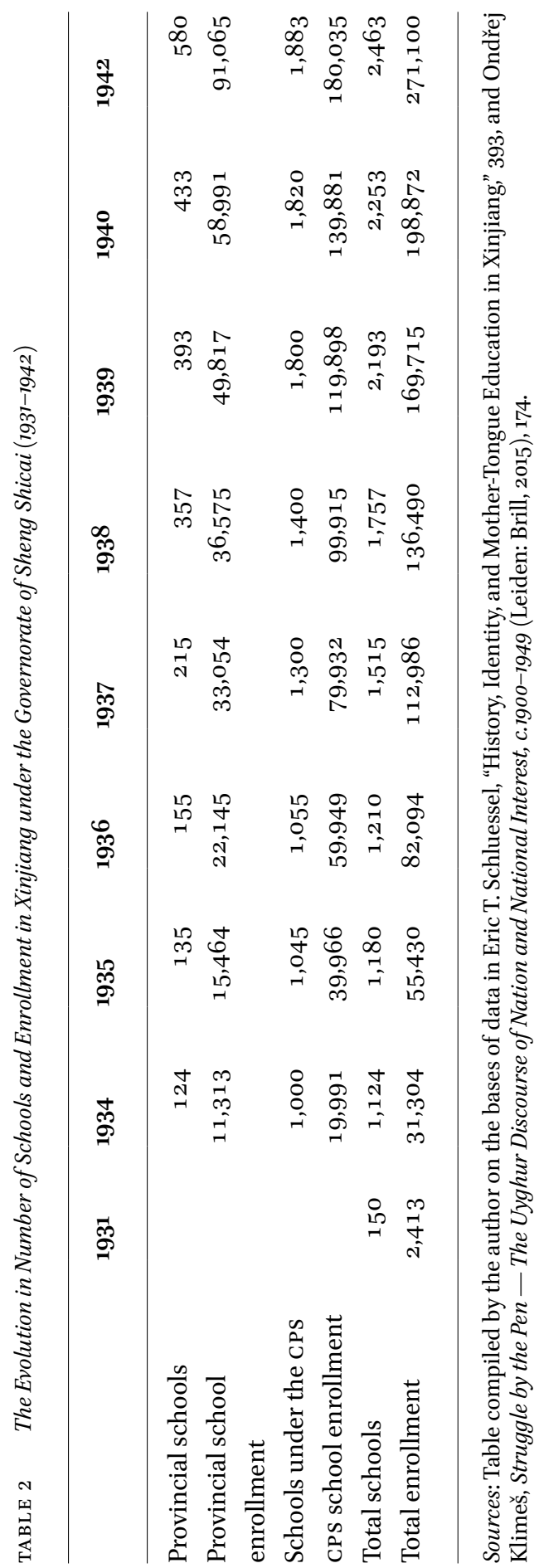


and 32 Han. ${ }^{70}$ Many of the Uyghur students were Ili Uyghurs. The disproportionate presence of Han vis-à-vis their relative share in the population suggests several explanations: perhaps more Han had the prerequisites for such studies, perhaps there was less cultural resistance against sending students to the USSR among Han families as there was among Muslims in the south of Xinjiang, or perhaps there was an unstated preference to sustain a Han technical and bureaucratic elite.

\section{Final Comments and Epilogue}

Of course, despite Sheng Shicai's Soviet-backed initiatives aimed at improving Xinjiang and its society, the nature of his rule, the wicked consequences of good intentions, or the collision between the latter and reality, and Moscow's dominant presence and patron-client relations in the province caused friction and resistance among several segments of society. Despite promises and attempts to "indigenize" formal administration and the police, Han domination of these institutions extended far beyond their relative share of the population. Local artisans and merchants heavily resented the influx of subsidized or duty-free Soviet consumer goods, as well as confiscations of their products either to line the pockets of regime cronies or to repay debts to the USSR. Xinjiang's society also despised the governorate's Soviet-style secularization campaigns among the Muslim population (1935-1937) and its purges of alleged "Fascist, Trotskyite, and separatist plotters" and "Japanese agents" in 1937-1938.71

These purges took a heavy toll on the local Turkic, Han, and Hui communities and émigré Russian elites. They also had an unsettling effect on society, since political purges were often a smokescreen for settling banal personal or economic rivalries. All this, and Sheng Shicai's increasingly erratic, if not paranoid, behavior in anticipation of a Soviet defeat following the invasion and occupation of the western USSR by German and German-allied forces in summer 1942 (leading to a temporary, yet abrupt, Soviet withdrawal from Xinjiang) and Guomindang defeat after the Japanese advanced into some of its strongholds in eastern China in summer 1943, contributed to his gradual loss of control. Eventually, in the autumn of 1944, he opted to become the

70 Ibid.

71 Forbes, Warlords and Muslims in Chinese Central Asia, 154-155. Typically, depending on the source and account, the number of victims of the replica of the Great Terror in Xinjiang ranges from several hundreds to more than 100,000. Garver, Chinese-Soviet relations $1937-45,155$. 
Guomindang government's minister of agriculture and forestry minster and left Xinjiang for good. ${ }^{72}$

For over a decade, Sheng Shicai ran a ruthless, militarized police state in Xinjiang. He also acquired personal assets, including land in his jurisdiction, and benefited from certain trade monopolies. ${ }^{73}$ At the same time, the societal and ideological vision that originally had inspired him went beyond predatory and cynical calculations. It was driven by a sincere urge to uplift the native population by including them in a socialist and patriotic project.

He carried out a program that combined raw survival, idealism, and aspired statesmanship. The standard literature about Xinjiang should give Sheng Shicai more credit than the current passing mentions or clichés depicting him as a passive Soviet puppet or predatory warlord. Moscow's aid motives were more complex than just exploiting the abundant natural resources of Xinjiang. But the Soviet Union eventually did not need this for its sheer survival, even though it might have economically needed this "spare periphery" in case its war with the Axis powers and the occupation of the western parts of the USSR had lasted much longer. What we have here is a clear case of a quasi state, or at least an entity bearing much of its characteristics, that came into being following the disintegration or dysfunctionality of a state and great space, and which formed the political context for a project of internally driven as well as externallybacked social engineering. As such, it was a kind of precursor to other projects of aid-driven social engineering carried through, decades later, by an internationalized and privatized aid sector, the nature and dynamics of which were conceptualized by Fearon, Laitin, and Duffield.

The Governorate of Sheng Shicai was not unique in that respect. Similar multisector and state-building aid was provided by the Soviet Union in that period to other unrecognized de facto states in its wider borderland, like the Azerbaijan People's Government of Tabriz, the Kurdish Republic of Mahabad (which both briefly existed in northern Iran during the Iranian Cold War crisis of 1945-1946) and, of course, the second East Turkestan Republic of Kulja that emerged as a secular Turkic nationalist entity in three northwestern districts

72 For a detailed accounts on the unraveling and demise of Sheng Shicai's rule, see Forbes, Warlords and Muslims in Chinese Central Asia, 160-161 and Chan, "Shen Shih-Ts'ai's Reform Programs in Sinkiang," 380-381. He was eventually dismissed as "unreliable" from his new post in the Guomindang government too, and fled to Taiwan after the communist takeover in mainland China where he lived until he passed away of old age in summer 1970.

"Pravda o sobityakh v Sin'tszyane," anonymous report on Soviet-Guomindang relations in Xinjiang and on the situation in the province, RGASPI f.17 op.128 d.824 l.404, http:// digitalarchive.wilsoncenter.org/document/121823. 
of Xinjiang after Sheng Shicai's departure, and existed from late 1944 until fall $1949 .{ }^{74}$ It was eventually all set in what Alfred Rieber calls, without actually elaborating on it, "borderland opportunism."75 In our opinion, this term is adequate enough to identify a paradigm in which sociological and political conditions typical of borderlands are amplified by the weakening of state control on one or both sides of a border or frontier and thus create opportunities for both local and extraneous actors to champion aspired or ideologically aligned societies and to demonstrate the supremacy of the championed development model.

74 For the Tabriz and Mahabad republics, see Jana Forsmann, Testfall für die «Großen Drei»: die Besetzung Irans durch Briten, Sowjets und Amerikaner, 1941-1946 (Cologne and Weimar: Böhlau-Verlag GmbH, 2009), 114-127. For the role of Soviet assistance to East Turkestan, see David D. Wang, Essays on Social Disturbance in Xinjiang in the 1940s, NIAS Report Series, no. 36 (Copenhagen: Nordic Institute of Asian Studies): 52-68, Valerii Barmin, “Politika vybora. Vzaimootnosheniya Sovetskogo Soyuza i Sin'tszyana posle samorospuska Vostochno-Turkestanskoi Respubliki (1946-1947 gg.)” Comparative Politics, no. 4 (2011): 89-97; Economic Research Committee of the USSR, "Proposals of the Economic Research Committee of the USSR Council of Ministers in connection with the Situation in Xinjiang" (translation), September 10, 1947, RGASPI f. 17, op. 162, d. 38, 1l. 202-208, http:// digitalarchive.wilsoncenter.org/document/121810.

75 Alfred J. Rieber, Stalin and the Struggle for Supremacy in Eurasia (Cambridge: Cambridge University Press, 2015), 396. 